\title{
Capabilities, Economic Development,
}

\section{Sustainability}

\author{
By Jan Fagerberg* and Martin Srholec**
}

\begin{abstract}
The capability concept is commonly used in analyses of firms, however, as this paper shows, it may also be used at the level of nations. Factor analysis is used on a broad set of relevant indicators to derive composite measures of national technological and social capabilities. The data covers 114 countries worldwide on different levels of development for the period 1995-2013. The paper then analyzes the relationships between these capability measures and economic development, defined in various ways, and controlling for other relevant factors. The results suggest that improving national technological and social capability is a must for achieving (sustainable) economic development and improving living conditions.
\end{abstract}

*) Jan Fagerberg, IKE, Department of Business and Management, Aalborg University Fibigerstraede 4, DK-9220 Aalborg Ø, Denmark; Center for Technology, Innovation and Culture (TIK), University of Oslo, P.O. Box 1108 Blindern, N-0317 Oslo, Norway; Centre for Innovation, Research and Competence in the Learning Economy (CIRCLE), Lund University, P.O. Box 117, SE-221 00 Lund, Sweden; mail: jan.fagerberg@tik.uio.no

**) Martin Srholec, Centre for Innovation, Research and Competence in the Learning Economy (CIRCLE), Lund University, P.O. Box 117, SE-221 00 Lund, Sweden; CERGE-EI, Economics Institute, Academy of Sciences of the Czech Republic, P.O. Box 882, Politických vězn̆ů 7, Prague 1, 111 21, Czech Republic; mail: martin.srholec@ circle.lu.se.

Acknowledgements: Financial support from the VINNOVA Core Funding of Centers for Innovation Systems Research project 2010-01370 on 'Transformation and Growth in Innovation Systems: Innovation Policy for Global Competitiveness of SMEs and R\&I Milieus' and the Czech Science Foundation (GAČR) project P402/10/2310 on "Innovation, productivity and policy: What can we learn from micro data?" are gratefully acknowledged. Earlier versions of the paper were presented at the conference on "Dynamic Capabilities and the Sustainable Competitiveness of Firms and Nations", October 11, 2012, St. Petersburg, Russia and the ASIALICS Conference, September 25-27, 2014, Daegu, Korea. The paper has benefitted from comments and suggestions from participants at these events. All usual caveats apply.

For publication in Cambridge Journal of Economics 2017 


\section{Introduction}

One of the most challenging questions in economics is this: Why do some countries perform so much better economically than others over long period of time? This is of course a matter of great theoretical and practical importance, and for this reason it has attracted interest from economists for centuries. In fact, already Adam Smith struggled with this question. And, as the below quotation from Friedrich List - in a rebuttal to Smith's reasoning about the subject - shows, the idea that this has something to do with a country's capability to absorb, exploit and create knowledge has been around for a long time.

"The present state of the nations is the result of the accumulation of all discoveries, inventions, improvements, perfections and exertions of all generations which have lived before us: (...) every separate nation is productive only in the proportion in which it has known how to appropriate those attainments of former generations and to increase them by its own acquirements" (List 1841, p. 113). ${ }^{1}$

Nevertheless the issue continues to be surrounded by controversy. One of the reasons has to do with resistance by many economists to the use of concepts such as knowledge and capabilities in connection with analyses of how countries perform. Such factors, it is argued, are attributes of individuals, not collectives. What economists should do, following this view, is to analyze economic development as the result of interaction between individuals that seek to maximize their own welfare. However, whatever the merits of this approach, what seems clear is that it substantially reduces the range of phenomena that the analyst can meaningfully say something about. In many cases policymakers' need for advice is instead met by a more practically oriented literature, often coming from the consultancy industry, based on the exploration of popular concepts, frameworks and exemplars. With respect to nations a typical example is the construction of composite indicators of "competitiveness" ranking countries according to how competitive, hence successful, they are (IMD 2015, WEF 2015). Although the construction of these indicators is often almost void of theory and based on very simple empirical methods, the interpretation of reality they convey and the advice this leads to receive much attention in the media and among policy-makers.

Arguably, economists should be able to do better. As a starting point it would be helpful to recognize that collectives such as firms, organizations and nations are more than the mere sum of their parts. They are also repositories of knowledge, institutions and resources, that is, capabilities, which significantly influence their efforts (and the outcomes of these efforts) with respect to the creation of economic value (Dosi et al 2008, Lawson 1999, Teece 2010). It is sometimes argued that use of concepts such as capabilities at the country level implies wrongly applying firm-level theories to the analysis of entire nations. However, although there are differences between countries and firms, there are also similarities that should not be overlooked. For example, the economic environment in which these entities operate, with its capitalist, knowledge-based dynamics, is essentially the same, and so are many of the factors that influence their performance. Both firms and countries are organized entities in which populations, based on their skills and resources, interact to create value, which is then distributed across the population according to certain criteria. Moreover, they both have systems of governance which significantly influence the creation and distribution of economic value and that affect their performance. Hence, using related concepts and understandings to analyze some of these challenges may have some merits.

The structure of the paper is as follows. Section 2 discusses in more detail the relation between knowledge and economic development, and the role of capabilities in making the most out of this relationship, at different levels of analysis. The central focus is on the national level. How technological and social capabilities can be measured is the topic under consideration in Section 3, which uses factor analysis on a broad set of relevant indicators to derive composite measures of national capabilities. The subsequent section explores the relationships between capability building and (sustainable) economic development, controlling for the impact of other potentially relevant variables. Finally, Section 5 presents the conclusions from the study and points to challenges for future research. 


\section{Knowledge, Economic Development and Capabilities ${ }^{2}$}

Most people today would easily accept the view that knowledge and development are two sides of the same coin. But this is not the way growth and development normally has been analyzed in economics. Rather, from the classical political economists onwards, growth and development has been seen as arising from accumulation of (physical) capital.

This tendency to reduce technology to machinery (or knowledge to artefacts) was something that not only affected economic orthodoxy. Even a highly heterodox economist such as Torstein Veblen argued along these lines in what may have been the first scholarly attempt to analyze catch-up processes in the world economy (Veblen 1915). In earlier times, Veblen argued, the diffusion of technology had been hampered by the fact that technology was mostly embodied in persons, so that migration of skilled workers was a necessary prerequisite for its spread across different locations. However, according to Veblen, the advent of "machine technology" changed this logic completely (ibid. p. 191). In contrast to the conditions that had prevailed previously, he argued, this new type of knowledge "can be held and transmitted ... and the acquisition of it by such transfer is no laborious or uncertain matter" (ibid.). Hence, because of these changes, catch-up should be expected to be relatively easy and was under "otherwise suitable circumstances" largely "a question of the pecuniary inducement and ... opportunities offered "' (ibid. p. 192).

This optimistic mood with respect to what could be obtained through participating in technology diffusion came to be shared by most neoclassical economists in the early post-war period. According to Robert Solow, the most famous contributor to the development of the neoclassical theory of economic growth (Solow 1956), knowledge - or technology - should be regarded as a public good freely available to anybody with a desire to share it independent of their background or location. It follows that it should be expected to benefit everybody to the same extent. This was also the assumption adopted in subsequent applied research based on this perspective. Edward Denison, the leading researcher of cross country differences in economic growth in the Western world in the early post war period, put it as follows: "Because knowledge is an international commodity, I should expect the contribution of advances of knowledge (...) to be of about the same size in all the countries..." (Denison 1967, p. 282). Hence, following this approach, knowledge should be expected to be a powerful force of catch-up and convergence in the global economy. ${ }^{3}$

However, these optimistic predictions have not always been confirmed in reality (Fagerberg and Srholec 2005, Milanovic 2009). For example, during the 1980s and 1990s, what was called "lost decades" for development (Easterly 2001), the difference between the poor and the rich part of the world was hardly reduced at all. One important reason for the failure of these predictions, we shall argue, has to do with the role of technology and its contribution to economic development. Arguably, there is no such thing as a worldwide stock of homogenous knowledge that flows across the globe at the speed of light and which everybody can exploit as much as they like. Rather there are many different types of knowledge and knowledge holders. Not all knowledge is scientific, as Friedrich von Hayek pointed out long ago (Hayek 1945). Much knowledge is practical and context specific (which does not make it less useful economically of course). Knowledge is also widely distributed across actors and contexts. As Hayek repeatedly stressed it is totally impossible for any actor, being a person or a firm (or a government for that sake), to know "everything" that may be relevant for the solution of an economic problem (what is often called "perfect knowledge"). In fact, just to identify what the relevant areas of knowledge are and how these can usefully be approached may be quite challenging.

Even in the case when the relevant knowledge can be identified, is codified and easily accessible, there is no guarantee that it will be successfully transferred. The knowledge may for example be difficult to understand and absorb. Higher education - even a doctorate or a whole group of people with such qualifications - may be required. Hence, it not sufficient to have access to knowledge, you must also have the necessary capabilities to understand, absorb and exploit it. Building such capabilities may be 
demanding, costly and time-consuming. Moreover, firms cannot rely on only one type of knowledge. They need to be able to access, absorb, combine and use many different types related to, for example, finance, logistics, products, markets, production etc. Access to necessary resources, such as ICTs, means of transport and skilled labour, and knowledge about how to access, keep and exploit those, is also crucial. It is of little help, say, to be aware of some promising knowledge if you cannot get hold of the resources necessary to reap the potential benefits from its exploitation.

Hence, if economic development primarily is about knowledge, then it must also be about the abilities of social actors to engage in the process of accessing, absorbing and using knowledge, so that income and welfare grow. Under capitalist conditions the most important social actor in this respect is the firm (Nelson and Winter 1982). From this perspective the gradual enhancements of firm's capabilities in accessing, absorbing and using knowledge must be regarded as a crucial factor in economic development (Cohen and Levinthal 1990). The Korean development scholar Linsu Kim suggested the term "technological capability" ${ }^{4}$ for this phenomenon. He defined it as "the ability to make effective use of technological knowledge in efforts to assimilate, use, adapt and change existing technologies, (....) to create new technologies and to develop new products and processes..." (Kim 1997, p. 4).

Kim's analyses were based on lessons from how Korean electronics firms, such as Samsung, gradually upgraded from a passive role of implementing imported technology, to a more active role of introducing incremental improvements, and eventually ventured into the forefront of innovation-based competition. He therefore distinguished between different layers of technological capability depending on the complexity of the challenge: production capability, investment capability and innovation capability. Production capability - the most basic requirement - is needed to operate productive facilities efficiently. Investment capability is required for the arguably more challenging task of establishing new productive ventures. Finally, innovation capability is seen as necessary for the development of new goods or services that better meet the requirements of the market. Kim expected the requirements to become more stringent, in particular with respect to innovation capabilities, as countries climb up the development ladder. Thus, following his view, for a firm or country in the process of catching up, the appropriate level of technological capability is a moving target. ${ }^{6}$

Having pointed out the important role that firm level technological capabilities play in the process of development we now turn to question of how the development of such capabilities depends on the firm's environment. Firms are not isolated islands and their performances are also influenced by the characteristics of the environment in which they operate. This was emphasized by among others the economic historian Moses Abramowitz, who used the term "social capability" for this aspect

(Abramovitz 1986). He defined it as "countries' levels of general education and technical competence, the commercial, industrial and financial institutions that bear on the abilities to finance and operate modern, large-scale business, and the political and social characteristics that influence the risks, the incentives and the personal rewards of economic activity" (Abramovitz 1994, p. 25).

Many of the concerns that led Abramovitz to focus on the role of economic, social, institutional and political aspects in development are also central in the more recent literature on "national innovation systems" (NIS). The NIS concept first appeared in work by Christopher Freeman (Freeman 1987), Bengt Åke Lundvall (Lundvall 1992) and Richard Nelson (Nelson 1993), and this analytic framework has since been extensively used in both scholarly and policy-analytic work (Sharif 2006). The concept has been used in a narrow as well as a broader sense (Edquist 2004). The narrower definition of the national innovation system includes innovative firms and the public research infrastructure with which they interact in varying degrees (Nelson 1993). The broader definition, which arguably is closer to Abramovitz' reasoning, extends this to all learning and innovation activities in a country regardless of where these take place (Lundvall 1992, Edquist 2004).

Although initially developed for firms, the technological capability concept has also been applied to whole industries or countries. Sanjaya Lall, in a survey of the literature (Lall 1992), emphasized three aspects of what he called "national technological capability": the ability to mobilize the necessary (financial) resources and use them efficiently; skills, including not only general education but also specialized managerial and technical competence; and "national technological effort", which he 
associated with measures such as $\mathrm{R} \& \mathrm{D}$, patents and technical personnel. He also made a distinction between technological capabilities proper and their economic effects, which, he noted, also depend on the incentives that economic agents face whether coming from political decision-making (governance) or embedded in more long-lasting institutions (the legal framework for example). This reasoning is of course very similar to that of Abramovitz.

In conclusion, the discussion so far leads to two propositions: 1) that generation of technological capabilities is a must for countries that wish to catch up and 2) that the degree of success in doing so also depends on wider economic, social, institutional and political factors (which hence needs to be taken into account). The following section considers how these factors can be measured, while section 4 considers the relationship between capability building and economic (sustainable) development, controlling for other potentially relevant variables.

\section{Measuring national capabilities}

The approach that will be pursued here is to assemble a set of indicators considered relevant for the phenomenon we wish to capture and construct a composite variable. In this respect, the underlying assumption is that indicators reflecting the same dimension of reality should be expected to be strongly correlated so that we can use factor analysis for this purpose. ${ }^{7}$

A challenge in empirical analyses of this type is to get high quality information on all the dimensions of reality that we wish to take into account for a sufficiently large number of countries and long enough time-span. Typically there is a trade-off between availability of high quality information and the size and composition of the sample. Indeed, many potentially interesting indicators only exist for a small number of (mostly) developed economies. Annual data may also be problem, since many countries do not supply the type of information we wish to use on a yearly basis (and the years for which data exists may differ across countries). Balancing the quest for high-quality of information on the one hand against sample size and time period on the other hand, led to the choice of a cross-section sample of 114 countries on different levels of development between 1995 and 2013 (or the nearest year available).

In the case of technological capability the indicators taken into account here include the quality of a country's research system (as reflected in scientific publications), invention and innovation (as measured by patent applications and R\&D expenditure) and development of the ICT infrastructure (proxied by internet users). While the two former dimensions come close to what Kim may had in mind with his concept "innovation capability", the latter may also be relevant for what he called "production" capability, since access to state of the art ICT is very important for firms' ability to produce and market goods and services and compete in global markets. With respect to social capability, we were able to include two broad dimensions, the first of which is the skill-level of the population (as reflected in primary, secondary and tertiary attainment and literacy). A second dimension refers to the quality of the governance in a country. Indicators taken into account in this case include measures how effective the government is, the extent to which corruption is a problem and, finally, whether law and order prevails. ${ }^{8}$ Further information on definitions and sources of the indicators of technological and social capabilities can be found in Appendix.

Although the indicators taken into account cover many relevant dimensions, there were also certain aspects that we were not able to measure as well as we ideally would have liked. For example, both Kim and Abramovitz emphasized the importance of managerial capacity and supporting sources of finance. We are, however, not aware of any source of information that can be used to measure managerial capacity, apart from perhaps the availability of highly qualified labour (tertiary attainment, included in the analysis), which is arguably much broader than what Kim and Abramovitz had in mind. The same problem holds for supporting sources of finance. For instance, with respect to the ability of organizing and financing new ventures, what Kim called "investment capability", supply of venture 
capital might perhaps have been a relevant indicator. But unfortunately such information was only available for some of the countries included in our data-set and could therefore not be taken into account. Failing to do so, we considered broader measures of financial development, such as the size of a country's financial market, but eventually sided against their inclusion because we found their relationship to a country's capability to exploit knowledge commercially to be problematic. Indeed, as some recent research suggests (see Fagerberg and Srholec 2016 and references therein), excessive "financialization" may equally well be a burden for the economy. Finally, as suggested by Abramovitz, it would have been interesting to be able include indicators of informal institutions, such as culturally embedded norms or "social capital", but again lack of available data for a sample of the present size precluded this. ${ }^{9}$

The factor analysis (Table 1) leads to the identification of three different capabilities, labelled Technology, Education and Governance, respectively. Technology is highly correlated with R\&D, patenting, scientific publication and the proliferation of the internet but also, to a lesser extent, with tertiary and secondary attainment. Education loads particularly highly on the two most basic education indicators, literacy and primary attainment but also on secondary and tertiary attainment. Finally, Governance is highly correlated with government effectiveness, (lack of) corruption and the prevalence of law and order.

\section{Table 1. Capabilities: Results of the factor analysis}

\begin{tabular}{l|c|c|c|}
\multirow{2}{*}{} & \multicolumn{3}{|c|}{ Factor loadings } \\
\cline { 2 - 4 } & Technology & Education & Governance \\
\hline Scientific and engineering articles & 0.60 & 0.04 & 0.37 \\
USPTO patent applications & 0.86 & -0.06 & 0.01 \\
R\&D expenditures & 0.68 & 0.01 & 0.29 \\
Internet users & 0.56 & 0.27 & -0.05 \\
Tertiary attainment & 0.44 & 0.52 & -0.01 \\
Secondary attainment & 0.37 & 0.63 & -0.04 \\
Primary attainment & -0.12 & 0.78 & 0.16 \\
Literacy & -0.05 & 0.93 & 0.03 \\
Government effectiveness & 0.03 & 0.07 & 0.90 \\
(Lack of) corruption & 0.01 & -0.05 & 0.98 \\
Law and order & 0.02 & 0.08 & 0.90
\end{tabular}

Note: The extraction method is principal factors; oblique oblimin rotation; based on pooled data in 114 countries in 1995 and 2013, hence 228 observations in total; 0.76 proportion of eigenvalues accounted for using the trace of the correlation matrix as the divisor. 
Figure 1 plots the development of a country's technological capability over the period 1995-2013 against its initial level in 1995. In this way four quadrants appear. Up to the left, in the quadrant labelled "losing momentum", we find countries with a high but stagnating (or declining) technological capability. Very few countries appear in this category (Ukraine and Russia are the most obvious examples). In contrast the countries in the top right quadrant combine a high initial capability-level with an above average capability-increase. Hence, these are countries that are "moving ahead" technologically. Korea, Taiwan, Israel and Finland are examples of countries that particularly excel in this regard, but many other developed countries also belong to this category. Another group of countries with above average performance can be found down to the right. These countries, a mixed crowd of Asian (China for instance) and European countries (from the Southern and Eastern part of the continent), are "catching up" technologically from a relatively low initial level. Finally, in the quadrant down to the left we find countries that are "falling behind" technologically, i.e., countries that combine a low initial level with below average performance. Many countries in Africa, LatinAmerica and Asia belong to this category.

Figure 1. Technology (1995-2013)

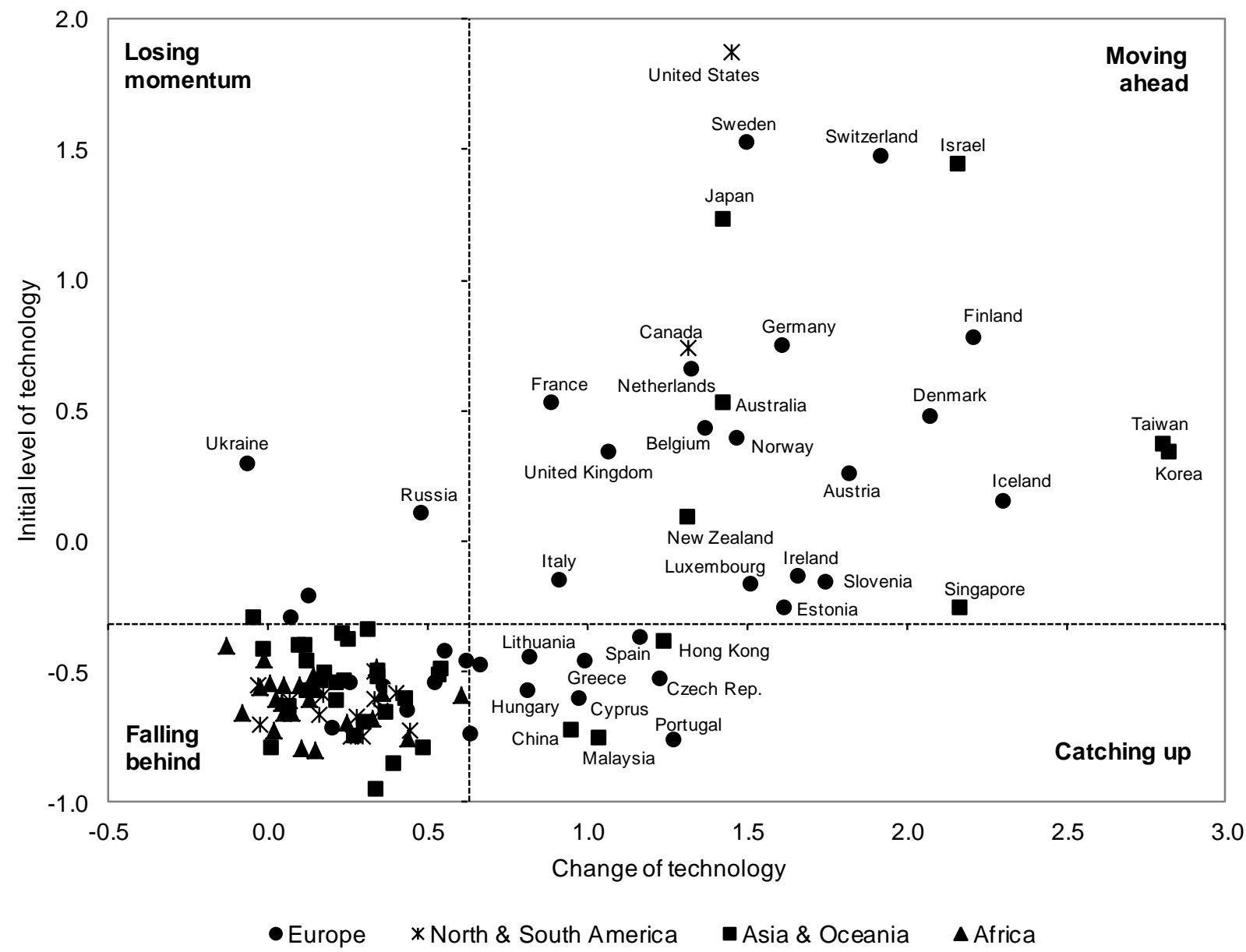

For technological capability what can be observed is a strong tendency towards divergence, with the great majority of countries either moving ahead or falling behind. However, when it comes to 
education (Figure 2) there is clearly more convergence going on, with many highly developed and previously Socialist countries in the "losing momentum category" and a number of developing countries "catching up". However, there are also some developing countries, particularly African ones, in the "falling behind" category, so the performance of the developing world in the educational area is far from uniform.

Figure 2. Education (1995-2013)

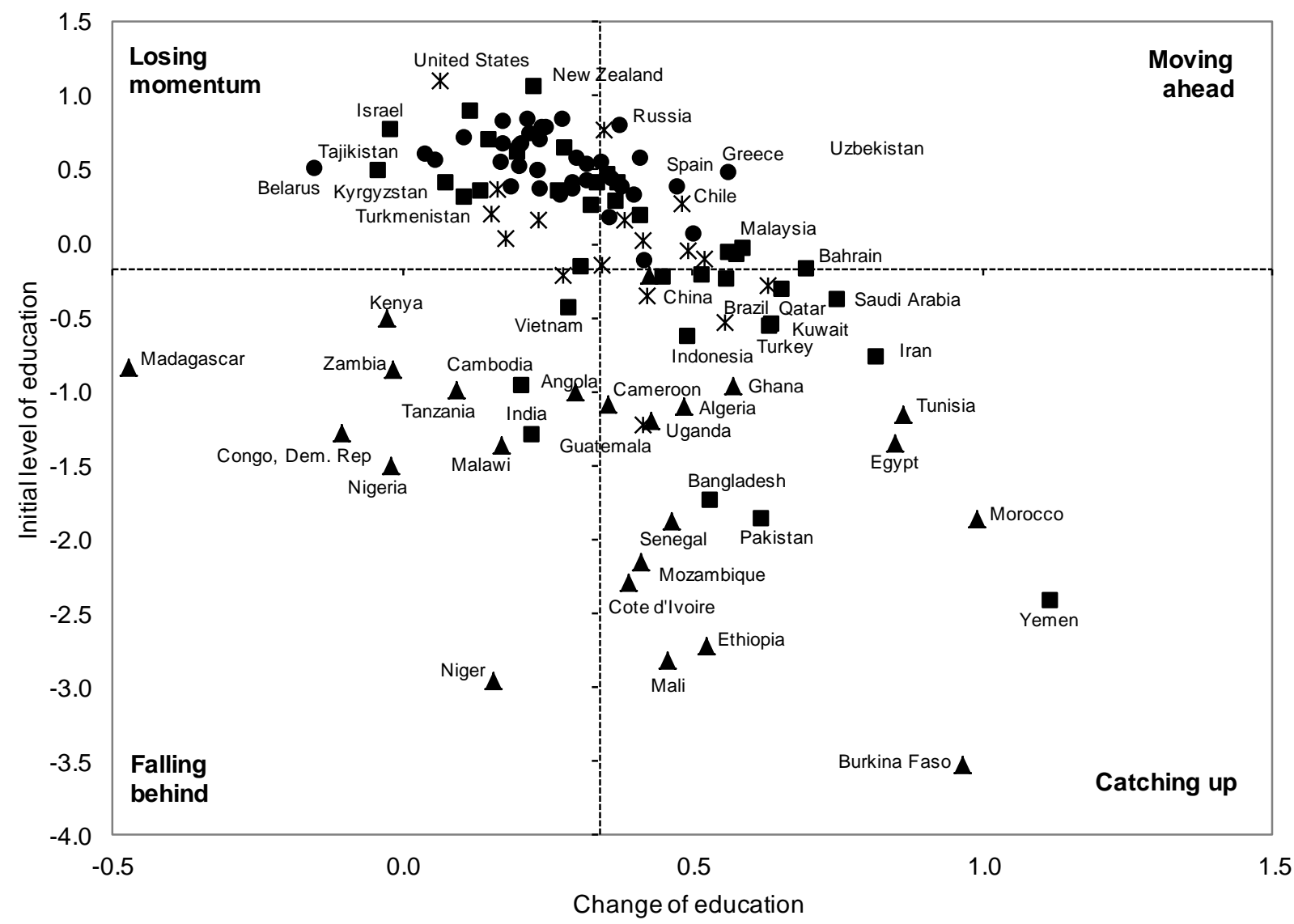

- Europe * North \& South America $\quad$ Asia \& Oceania $\Delta$ Africa

The tendency towards convergence in capability levels which could be observed in the case of education also holds for governance (Figure 3). In particular, many African, Asian and Eastern European countries improved their governance over this period, while it was the other way around for some developed countries (with well-developed governance systems at the outset). However, a number of previous Soviet republics, now independent, saw their governance deteriorate over the period, and this also holds for some developing nations. 
Figure 3. Governance (1995-2013)

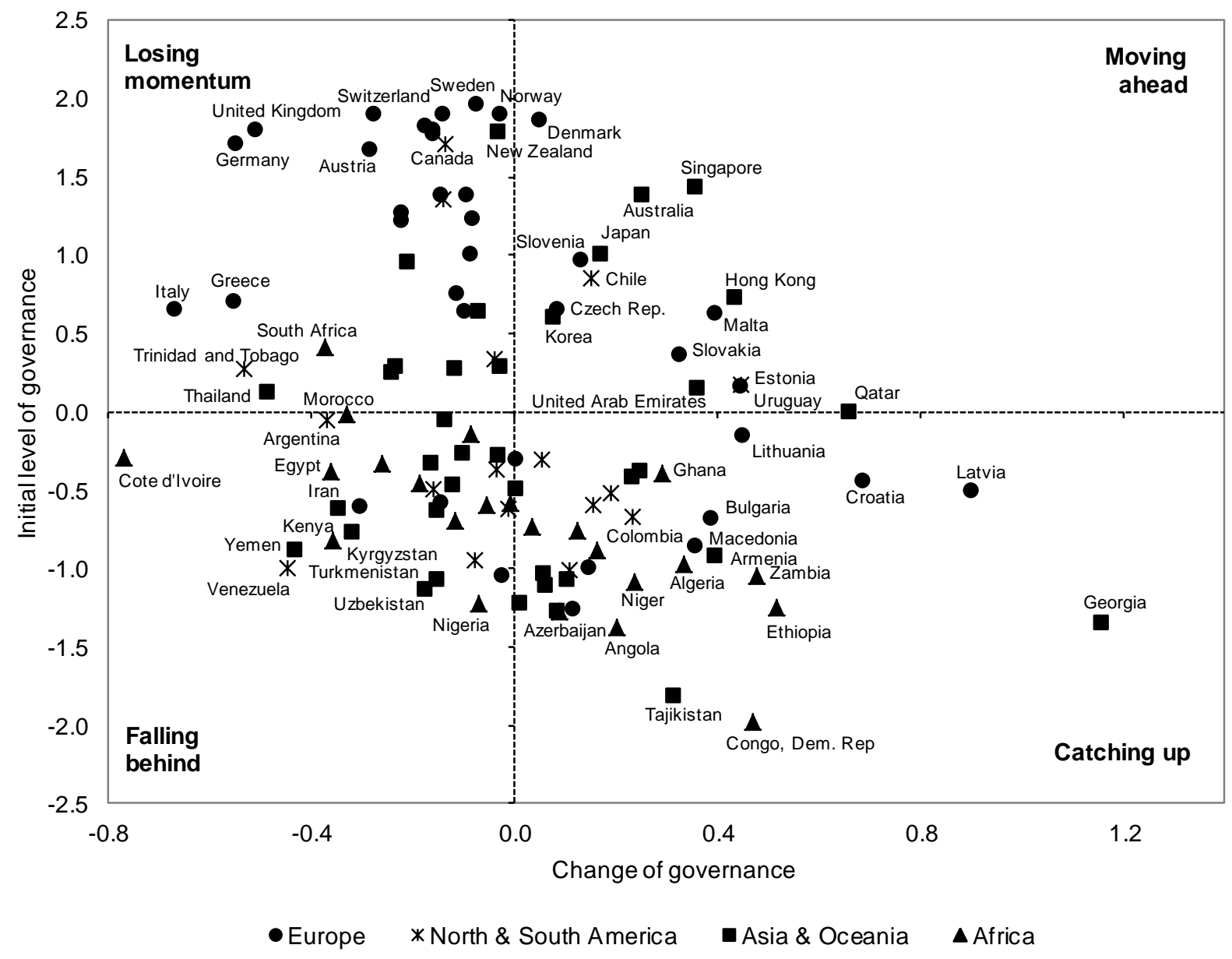

\section{Capabilities and economic development}

In this section we will explore the relationships between capabilities and economic development, variously defined, using an econometric approach. The sample is as previously a cross section of 114 countries between 1995 and 2013. The analysis that follows extends earlier work (Fagerberg, Srholec and Knell 2007, Fagerberg and Srholec 2008) on the subject in various ways. First, we are going to consider a more recent time period. Second, we aim for a richer treatment of technological capability (and its impacts) than what was possible previously. This allows us, for example, to include ICT infrastructure in a more satisfactory manner. Third, we experiment with measures of economic development that go beyond the traditional GDP concept, for example by adjusting for consumption of fixed capital and depletion of natural resources (World Bank 2011).

The empirical model used in this section to explore the relationships between capability-building and economic development is the standard conditional growth regression that was made popular by Barro (1991), hence the term "Barro-regression", although the model has been used earlier by among others Cornwall (1976). In the model a country's growth rate is regressed against its initial level of development and a number of so-called "conditioning factors". The less advanced a particular country 
is, the larger the potential for benefitting from more advanced technology already in use elsewhere is expected to be (hence the correlation between the growth rate and the initial level of GDP per capita should be expected to be negative). However the extent to which this potential is exploited also depends, as argued previously, on capabilities, which therefore are included here as conditioning factors along with a number of other control variables deemed to be relevant in the present case. These include external demand conditions defined as growth in world demand weighted by the product or market composition of a country's exports (see more detailed definition in the appendix), the degree of openness of the economy, the size of the economy measured by population and natural resource rents (the latter three are included as averages over 1995-2013 in logs).

Table 2. Capabilities and economic development: Regression results, iteratively re-weighted least squares, 1995-2013

\begin{tabular}{lcccc}
\hline & $G D P$ & $\begin{array}{c}\text { GDP } \\
\text { per capita }\end{array}$ & $\begin{array}{c}\text { Adjusted net } \\
\text { national income } \\
\text { per capita }\end{array}$ & $\begin{array}{c}\text { Life } \\
\text { expectancy } \\
\text { at birth }\end{array}$ \\
\hline Initial development level & $-0.75^{* * *}$ & $-0.59^{* * *}$ & $-0.28^{* * *}$ & $-0.71^{* * *}$ \\
& $(7.36)$ & $(5.75)$ & $(3.40)$ & $(15.75)$ \\
$\Delta$ technology & $0.25^{* *}$ & $0.28^{* * *}$ & $0.24^{* * *}$ & $0.18^{* * *}$ \\
& $(2.57)$ & $(2.82)$ & $(3.06)$ & $(3.74)$ \\
$\Delta$ education & $0.12^{*}$ & 0.00 & $0.11^{* *}$ & -0.02 \\
& $(1.92)$ & $(0.04)$ & $(2.15)$ & $(0.58)$ \\
$\Delta$ governance & $0.17^{* * *}$ & $0.29^{* * *}$ & $0.19^{* * *}$ & $0.13^{* * *}$ \\
& $(2.73)$ & $(4.45)$ & $(3.30)$ & $(3.73)$ \\
Control variables: & & & & \\
Export demand by product & $0.19^{*}$ & 0.07 & $0.22^{* * *}$ & 0.01 \\
& $(1.89)$ & $(0.67)$ & $(2.60)$ & $(0.08)$ \\
Export demand by market & $0.13^{*}$ & $0.16^{* *}$ & $0.44^{* * *}$ & $-0.06^{*}$ \\
& $(1.86)$ & $(2.29)$ & $(7.85)$ & $(1.76)$ \\
Export openness & $0.23^{* * *}$ & $0.22^{* * *}$ & $0.16^{* *}$ & -0.02 \\
& $(2.88)$ & $(2.70)$ & $(2.40)$ & $(0.38)$ \\
Population & 0.04 & $0.18^{* *}$ & $0.13^{* *}$ & 0.04 \\
& $(0.55)$ & $(2.39)$ & $(2.20)$ & $(1.02)$ \\
Natural resource rents & $0.25^{* *}$ & 0.02 & 0.07 & -0.06 \\
& $(2.33)$ & $(0.20)$ & $(0.83)$ & $(0.98)$ \\
\hline F-test & $17.38^{* * *}$ & $10.69^{* * *}$ & $16.21^{* * *}$ & $44.06^{* * *}$ \\
$\mathrm{R}^{2}$ & 0.43 & 0.30 & 0.32 & 0.27 \\
Number of observations & 114 & 114 & 93 & 114 \\
\hline
\end{tabular}

Note: Absolute value of robust t-statistics in parentheses. ${ }^{*}, * *, * * *$ denote significance at the 10,5 and 1 per cent levels. Beta values reported.

Table 2 contains the results. Four different regressions are reported, all using the iterativelyreweighted-least-squares estimator suggested by $\mathrm{Li}$ (1985). In the first case the dependent variable is economic growth, i.e., growth of GDP as conventionally defined (see appendix for sources and definitions). Then a regression with growth of GDP per capita (that is, growth of labour productivity) as dependent variable is reported. In the third column growth of labour productivity is adjusted for consumption of fixed capital and depletion of natural resources. Finally we include a version with growth of life expectancy as the dependent variable. ${ }^{11}$ With respect to the potential for improvement and the role of capability building in bringing this about the results are remarkably consistent across the different specifications. In particular, improving technological capability and the quality of governance have positive and significant effects in all cases. The results for the education variable, which primarily reflects basic education, are more mixed, but it may be noted that its impact increases (and becomes more significant) when sustainability concerns are taken into account. Interestingly, the 
same holds for the demand-variables, the relevance of which is consistent with post-Keynesian theory (Fagerberg 1996).

To analyze the implications of these findings for countries with different characteristics in more detail we first undertook a hierarchical cluster analysis (using Ward's method) on the (initial) levels and changes of the three capability variables constructed in this paper. For the purpose of the analysis a division into four clusters was selected (Table 3 and Appendix Table A4). First there is cluster of 28 countries from Africa and Asia with very poorly developed technological and social capabilities, and little progress in improving these, except for (basic) education. We label this cluster the "laggards". The second cluster, consisting of 34 countries from Latin-America, Asia and (to some extent) Africa, distinguishes themselves from the "laggards" by having much better education and governancesystems. They also experience much more rapid growth in technological capability. Hence, they are to a certain extent alt least - engaged in "catch-up", the name chosen for this cluster. The "transition" cluster consists of 18 countries many of which are former Soviet republics. Their technological capability and education-level is higher than in the cases described above but their governancesystems functioned very poorly at the outset. Despite some improvements, this continues to be the case. Finally, there is a cluster of 34 developed economies, hence the label, with much more advanced technological and social capabilities than elsewhere. And not only are their technological capabilities higher, they also increase much faster than elsewhere, as shown above.

Table 3. Groups of countries by capabilities: Clustering results, Ward's linkage hierarchical cluster analysis, initial level in 1995 and change over 1995-2013.

\begin{tabular}{l|ccc|ccc} 
& \multicolumn{3}{|c|}{ Initial level } & \multicolumn{3}{c}{ Change } \\
\hline Cluster & Technology & Education & Governance & Technology & Education & Governance \\
\hline Laggards & -0.60 & -1.61 & -0.80 & 0.13 & 0.42 & 0.01 \\
Catch-up & -0.64 & -0.08 & -0.13 & 0.37 & 0.43 & -0.01 \\
Transition & -0.38 & 0.45 & -0.96 & 0.22 & 0.20 & 0.18 \\
Developed & 0.27 & 0.59 & 1.30 & 1.53 & 0.26 & -0.10 \\
\hline Total & -0.32 & -0.17 & 0.00 & 0.63 & 0.34 & 0.00
\end{tabular}

In Table 4 we provide a decomposition of the estimated growth performance of these four groups (based on the third regression reported in Table 2). The prediction is reasonable for most country groupings, confirming that the model explains the growth pattern of the last two decades rather well. Nevertheless, the prediction overestimates somewhat the growth of the laggards, while it is the other way around for the transition countries. The analysis confirms that differences in the scope for imitation given by the initial development level are crucial for explaining differences in growth. According to the decomposition, the developed countries should for this reason alone be expected to grow about two percentage points less per year than the laggards. Besides the scope for imitation the most powerful explanatory factor for "why growth-rates differ" is changing technological capability. For example, this factor alone makes the developed countries grow nearly one and half percentage points faster than the laggards. Other factors also matter albeit less. For example, improved governance gives more than one third of a percentage point boost to the growth rate of the transition countries, which are also estimated to greatly benefit from favourable demand-conditions given by the composition of exports by markets (related to the strong revival of their mutual trade after a painful transition period in the early 1990s). 
Table 4. Explaining annual growth of adjusted net national income per capita: A decomposition, 1995-2013

\begin{tabular}{|c|c|c|c|c|c|c|c|c|c|c|c|c|}
\hline & \multirow[b]{2}{*}{$\mathrm{N}$} & \multirow[b]{2}{*}{$\begin{array}{l}\text { Actual } \\
\text { growth }\end{array}$} & \multirow[b]{2}{*}{$\begin{array}{c}\text { Estimated } \\
\text { Growth }\end{array}$} & \multicolumn{9}{|c|}{ Contribution of the explanatory factors to difference from the world average } \\
\hline & & & & $\begin{array}{c}\text { Initial } \\
\text { develop- } \\
\text { ment level }\end{array}$ & $\begin{array}{l}\Delta \text { tech- } \\
\text { nology }\end{array}$ & $\begin{array}{l}\Delta \text { edu- } \\
\text { cation }\end{array}$ & $\begin{array}{c}\Delta \text { gover- } \\
\text { nance }\end{array}$ & $\begin{array}{c}\text { Export } \\
\text { demand } \\
\text { by } \\
\text { product }\end{array}$ & $\begin{array}{c}\text { Export } \\
\text { demand } \\
\text { by } \\
\text { market }\end{array}$ & $\begin{array}{c}\text { Export } \\
\text { openness }\end{array}$ & $\begin{array}{l}\text { Popula- } \\
\text { tion }\end{array}$ & $\begin{array}{c}\text { Natural } \\
\text { resource } \\
\text { rents }\end{array}$ \\
\hline Laggards & 23 & 3.49 & 3.42 & 1.02 & -0.52 & 0.08 & 0.03 & 0.03 & -0.35 & -0.31 & 0.21 & 0.14 \\
\hline Catch-up & 27 & 3.06 & 2.96 & -0.05 & -0.30 & 0.08 & -0.06 & 0.08 & -0.03 & -0.01 & 0.12 & 0.04 \\
\hline Transition & 13 & 5.72 & 4.81 & 0.33 & -0.41 & -0.19 & 0.38 & -0.05 & 1.65 & 0.12 & -0.13 & 0.03 \\
\hline Developed & 30 & 1.59 & 1.56 & -0.89 & 0.89 & -0.15 & -0.24 & -0.21 & -0.77 & 0.06 & -0.04 & -0.20 \\
\hline
\end{tabular}

Note: Based on column 3 in Table 2. Average annual growth of adjusted net national income per capita in the world, i.e. the intercept, is estimated at 3.08 per cent. $\mathrm{N}$ is number of observations. 
The important role played by changes in technological capability may merit a more detailed analysis. Figure 4 reports the contributions from the various indicators that make up the composite technological capability variable. It is interesting to note the different roles that the various indicators play for the country groups. In many countries on a medium to low level of development the major contribution to growth of technological capability tends to come from diffusion of ICTs. This is particularly notable for the "catch-up" and "transition" groups. At a higher level of development, however, growing "innovation capabilities" as reflected by increases in science, R\&D and patenting are of much larger significance, as about three quarters of their high capability growth come from such sources.

Figure 4. Contribution to growth of technological capability

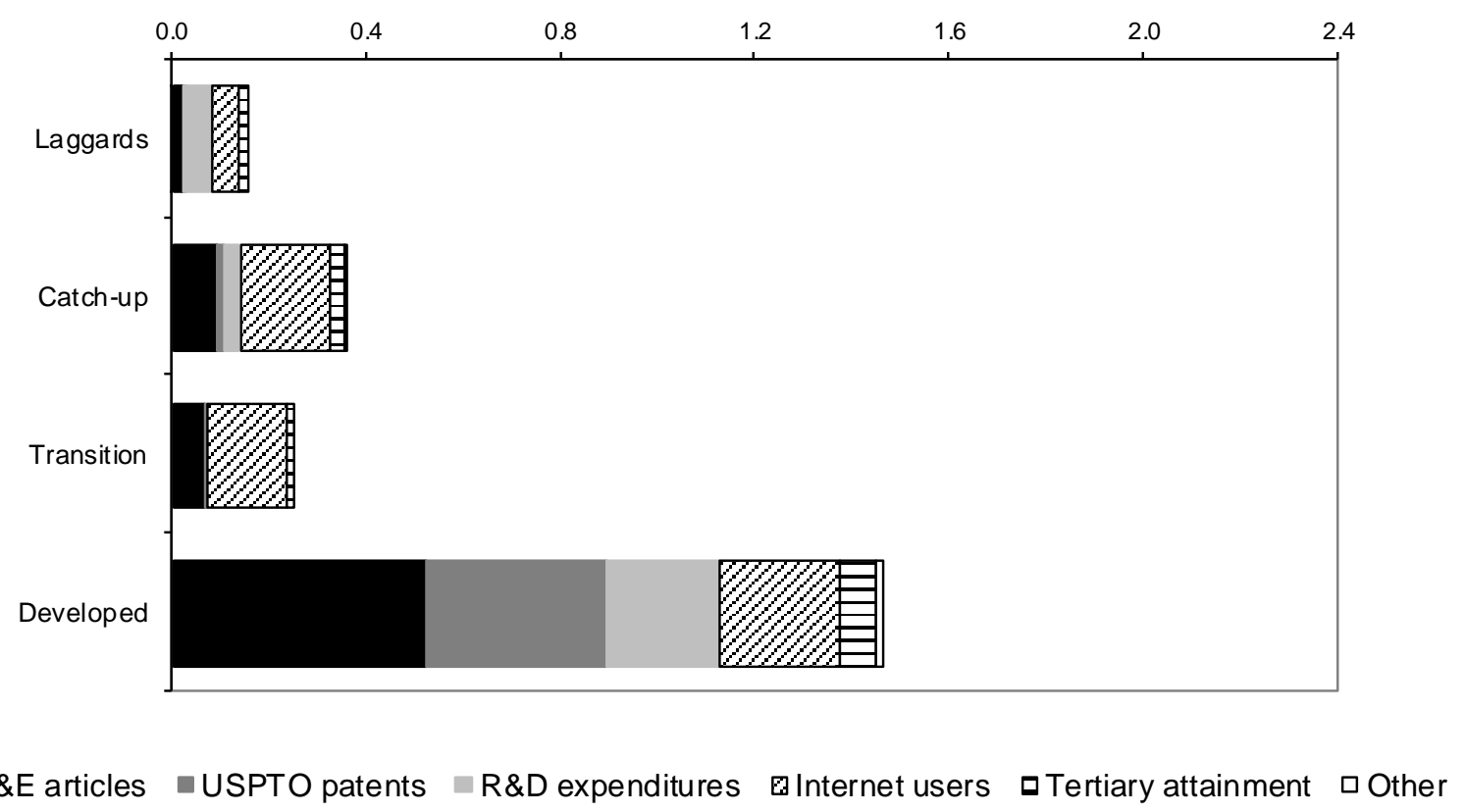

\section{Conclusions}

This paper has argued that concepts such as capabilities and competitiveness are not only relevant for firms (Teece 2010) but also for nations. Countries are more than mere sums of the characteristics of the individuals that live there. They are also repositories of knowledge, institutions and resources that underpin the economic activities within their respective borders. Such country-level characteristics influence the economic activities of its firms and citizens.

Previous research has identified two main types of capabilities, technological and social.

Technological capabilities refer to the ability to create and exploit knowledge to produce goods and services. Such capabilities are often firm-specific but are also influenced by environments in which firms operate, as firms increasingly depend on external sources for developing and improving their capabilities. Technological capability also has an important national dimension as countries regularly devote large resources (often channelled through dedicated public-sector organizations) to develop and maintain such capabilities. 
While technological capabilities to a large extent are attributes of firms, social capabilities are characteristics of the social environment that firms share, and that influence firm's operations in various ways, from being a source of much needed resources, such as skills, to for example providing an institutional and legal framework for firms' activities. Although politicians may influence the development of technological capability, and many examples testify to that, their say may be just as great when it comes to social capabilities.

The analysis in this paper highlights the important roles that technological and social capabilities play for economic development. This holds, as this paper shows, not only for growth of GDP as traditionally defined but also for output measures "beyond GDP" that adjusts for depletion of natural resources or a measure such as increased life expectancy. Thus, there is no conflict between improving technological capabilities and placing emphasis on sustainability and/or welfare. What may be worrying, however, is that national technological capabilities in many laggards are hardly growing at all, while in advanced countries technological capabilities are progressing very fast, implying technological divergence. How to reverse this trend represents a serious challenge. 


\section{References}

Abramovitz, M. 1986. Catching Up, Forging Ahead, and Falling Behind. Journal of Economic History 46, 386406.

Abramovitz, M. 1994. The Origins of the Postwar Catch-Up and Convergence Boom. In Fagerberg, J., Verspagen, B. \& von Tunzelmann, N. (Eds.) The Dynamics of Technology, Trade and Growth, Aldershot: Edward Elgar, 21-52.

Adelman, I. and Morris C. T. 1965. A Factor Analysis of the Interrelationship Between Social and Political Variables and Per Capita Gross National Product. Quarterly Journal of Economics, 79, 555578.

Barro, R. J., (1991) Economic Growth in a Cross Section of Countries. Quarterly Journal of Economics, 106, 407-443.

Barro, R. J. and Lee, J-W. 2010. A New Data Set of Educational Attainment in the World, 1950-2010. NBER Working Paper No. 15902, download on 21 November 2012, v. 1.2, 09/11.

Castellacci, F. and Natera, J. M. 2011. A new panel dataset for cross-country analyses of national systems, growth and development (CANA). Innovation and Development, 1, 205-226.

Cimoli, C., Dosi, G. and Stiglitz, J.E. (2009) Industrial Policy and Development - The Political Economy of Capability Accumulation, Oxford: Oxford University Press.

Cohen, W. M. and D. A. Levinthal (1990), 'Absorptive Capacity: A New Perspective on Learning and Innovation', Administrative Science Quarterly, 35, 128-152.

Cornwall, J. (1976) Diffusion, Convergence and Kaldor's Law. Economic Journal, 85, 307-314.

Denison, E. F. 1967. Why growth rates differ. Washington, DC: Brookings Institution.

Dosi, G., Faillo, M. and Marengo, L. 2008. Organizational Capabilities, Patterns of Knowledge Accumulation and Governance Structures in Business Firms: An Introduction, Organization Studies, $29,1165-1185$

Edquist, C. 2004. Systems of Innovation: Perspectives and Challenges. In Fagerberg, J., D. Mowery, and R. Nelson (eds), The Oxford Handbook of Innovation. Oxford: Oxford University Press, 181-208. 
Easterly, W. 2001. The Lost Decades: Explaining Developing Countries' Stagnation in Spite of Policy Reform 1980-1998. Journal of Economic Growth, 6, 135-157.

Fagerberg, J. 1987. A technology gap approach to why growth rates differ. Research Policy, 16, 87-99. Fagerberg, J. 1996. Technology and Competitiveness. Oxford Review of Economic Policy, 12, 39-51. Fagerberg, J. and Srholec, M. 2005. Catching up: What are the Critical Factors for success? Working Papers on Innovation Studies 20050401, Centre for Technology, Innovation and Culture, University of Oslo http://ideas.repec.org/p/tik/inowpp/20050401.html

Fagerberg, J., Srholec, M. and M. Knell 2007. The Competitiveness of Nations: Why Some Countries Prosper While Others Fall Behind. World Development, 35, 1595-1620.

Fagerberg, J. and Srholec, M. 2008. National Innovation systems, capabilities and economic development, Research Policy, 37, 1417-1435.

Fagerberg, J. and Srholec, M. 2009. Innovation systems, technology and development: Unpacking the relationships, in Lundvall, BA; Joseph, KJ; and Chaminade, C. (Eds) "Handbook of Innovation Systems and Developing Countries", Edward Elgar.

Fagerberg, J., Srholec, M., \& Verspagen, B. 2010. Innovation and Economic Development. In B. Hall, \& N. Rosenberg (Eds.), Handbook of the Economics of Innovation. Vol. II. North Holland, p. 833-872. Fagerberg, J., and Srholec, M. 2016. Global dynamics, capabilities and the crisis, Journal of Evolutionary Economics (DOI 10.1007/s00191-016-0453-9)

Fransman M. and K. King (eds) 1984. Technological capability in the third world, London: MacMillan.

Freeman, C. 1987. Technology Policy and Economic Performance: Lessons from Japan, London: Pinter.

Hayek, F. A. 1945. The Use of Knowledge in Society, American Economic Review, 35, 519-530.

$\begin{array}{lllll}\text { IMD 2015. IMD } & \text { World } & \text { Competitiveness } & \text { Yearbook }\end{array}$ (http://www.imd.org/research/publications/wcy/)

Kaufmann, D., Kraay, A. and Mastruzzi, M. 2014. Worldwide Governance Indicators, on-line. World Bank, http://info.worldbank.org/governance/wgi/index.aspx\#doc-sources, download on 13.6.2014. 
Kim L. 1980. Stages of development of industrial technology in a developing country: a model. Research Policy, 9, 254-277.

Kim, L. 1997. Imitation to Innovation: The Dynamics of Korea's Technological Learning, Harvard: Harvard Business School Press.

Lall, S. 1987. Learning to Industrialize: The Acquisition of Technological Capability by India, London: Macmillan Press.

Lall, S. 1992. Technological capabilities and industrialization, World Development, 20, 165-186.

Lawson, C. (1999) Towards a competence theory of the region, Cambridge Journal of Economics, 23, $151-166$

Li, G. 1985. Robust regression. In Exploring Data Tables, Trends, and Shapes, ed. D. C. Hoaglin, F. Mosteller, and J. W. Tukey, New York: Wiley, pp. 281-340.

List, F. 1841. Das Nationale System der Politischen Okonomie: Basel: Kyklos. The National System of Political Economy' by Longmans, Green and Co., London.

Lundvall, B. A., eds. 1992. National Systems of Innovation: Towards a Theory of Innovation and Interactive Learning. London, Pinter Publishers.

Milanovic, B. 2009. Global inequality recalculated: the effect of new 2005 PPP estimates on global inequality. Policy Research Working Paper Series 5061, The World Bank.

Nelson, R. R. and Winter, S. G. (1982) An Evolutionary Theory of Economic Change, Cambridge, Mass: Harvard University Press

Nelson, R. (eds) 1993. National Innovation Systems: A Comparative Analysis, New York: Oxford University Press.

OECD 2015. OECD.Stat. Paris: OECD, download on 15.8.2015.

PRS Group 2014. International Country Risk Guide: Table 3B: Political Risk Points by Component. Syracuse, NY: The PRS Group.

SCImago (2016) SCImago Journal \& Country Rank. Scopus database, Elsevier, http://www.scimagojr.com/countryrank.php

Sharif, N. 2006. Emergence and development of the National System of Innovation concept, Research Policy, 35 (5): 745-766 
Soete, L., Verspagen, B. and Ter Weel, B. 2010. Systems of Innovation, In B., Hall, \& N., Rosenberg (Eds.), Handbook of the Economics of Innovation Vol. II. North Holland, pp. 1159-1180.

Solow, R. M. 1956. A Contribution to the Theory of Economic Growth. Quarterly Journal of Economics, 70 (1), 65-94.

Srholec, M. and Verspagen, B. 2012. The Voyage of the Beagle into innovation: Explorations on heterogeneity, selection and sectors. Industrial and Corporate Change, 21, 1221-1253.

Teece, D. J. 2010. Technological Innovation and the Teory of the Firm: The Role of Enterprise-Level Knowledge, Complementaries, and (Dynamic) Capabilities In B., Hall, \& N., Rosenberg (Eds.), Handbook of the Economics of Innovation Vol. I., North Holland, pp-. 679-731

Temple, J. 1998. Initial conditions, social capital and growth in Africa, Journal of African Economies, 7, 309-347.

Temple, J. and P. A. Johnson 1998. Social Capability and Economic Growth. Quarterly Journal of Economics, 113, 965-990.

UNCTAD 2014. UNCTAD Handbook of Statistics, UNCTADstat on-line. Geneva: UNCTAD, download on 15. 8. 2014.

UNESCO 2015. UIS.Stat. Geneva: UNESCO Institute for Statistics, download on 15.8.2015.

USPTO 2014. Number of Utility Patent Applications Filed in the United States By Country of Origin, Calendar Years 1965 to Present (Last Modified: 06/05/2014). U.S. Patent and Trademark Office, http://www.uspto.gov/web/offices/ac/ido/oeip/taf/cst utlh.htm.

Veblen, T. 1915. Imperial Germany and the industrial revolution, New York: Macmillan.

WEF 2015. The Global Competitiveness Report 2015-2016 (http://reports.weforum.org/globalcompetitiveness-report-2015-2016)

World Bank 2011.The Changing Wealth of Nations: Measuring Sustainable Development in the New Millennium. New York: World Bank.

World Bank 2015. World Development Indicators (Last updated: April 2015). New York: World Bank. 


\section{Appendix (data \& sources)}

A brief overview of definitions and sources of the indicators is given in the table below. The main source of data is the World Bank (2015), SCImago (2016), USPTO (2014), UNESCO (2015), Barro and Lee (2010), PRS Group (2014), Kaufmann, et al. (2014) and UNCTAD (2014). The database has been complemented by international data from other sources such as Castellacci and Natera, (2011) and OECD (2015), while national sources were only used Taiwan if necessary.

Sample size and composition was given by the availability of data. The dependent and control variables were fully available for all countries in both periods, except only of the adjusted net national income. For the indicators of technological and social capabilities we used data form the nearest available year to 1995 and 2013. Although the selected indicators have broad coverage, in some cases there were missing values that had to be dealt with. A number of the advanced countries do not monitor literacy anymore. We assumed that all of these countries maintain $99.5 \%$ literacy. The remaining missing data were estimated using the impute procedure in Stata 11.2 (see the Stata 11.2 Manual for details). We based the estimation on data for the other indicators used to construct the capability measures. The number of observations (in both periods) estimated by the procedure is given in the last column of the following table.

Following Fagerberg, Srholec and Knell (2007), external demand is computed by weighting the growth of world demand by product or market $\left(g_{j}\right)$ (i.e. the log difference) with the initial composition (specialization) of each country's exports $\left(s_{i j}\right)$ :

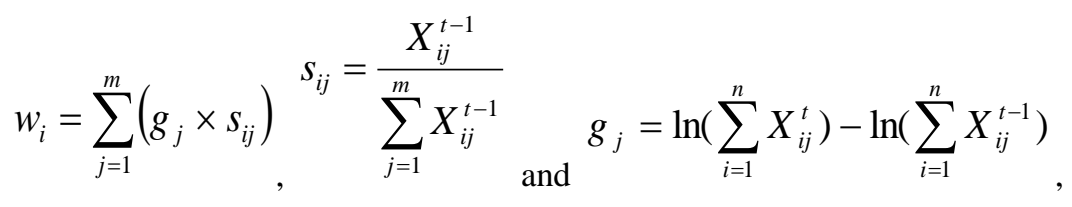


where $i$ the exporting country and $\mathrm{j}$ is either a product or a market, $X_{\mathrm{ij}}$ denotes the country's $i(i=$ $1 \ldots n)$ exports of a product group or to market $j(j=1 \ldots m)$ and $t-1$ and $t$ are two points in time. A high score indicates favourable demand conditions for a country's exports. Both merchandise trade and trade in services are included in the computation of demand by product, while only the former is available for demand by market. Demand by product is based on data for merchandise trade at 3-digit level of SITC, rev. 3, with 255 product categories and trade in services distinguished in three categories (transport, travel and other services). Demand by market is based on data for merchandise trade by 215 partner countries. 


\begin{tabular}{|c|c|c|c|}
\hline Indicator \& definition & Scaling & Source & $\begin{array}{c}\text { Estimated } \\
\text { observati } \\
\text { ons }\end{array}$ \\
\hline GDP: Gross Domestic Product in constant local currency units (LCU). & LCU & World Bank (2015) & 0 \\
\hline $\begin{array}{l}\text { GDP per capita: Gross domestic product converted to constant } 2011 \text { international dollars } \\
\text { using purchasing power parity rates. }\end{array}$ & $\begin{array}{l}\text { USD per } \\
\text { capita }\end{array}$ & World Bank (2015) & 0 \\
\hline $\begin{array}{l}\text { Adjusted net national income per capita: Gross national income minus consumption } \\
\text { of fixed capital and natural resources depletion converted to constant } 2011 \text { international } \\
\text { dollars using purchasing power parity rates. }\end{array}$ & $\begin{array}{l}\text { USD per } \\
\text { capita }\end{array}$ & World Bank (2015) & 21 \\
\hline Life expectancy at birth: The average number of years a newborn infant would live. & Years & World Bank (2015) & 0 \\
\hline $\begin{array}{l}\text { Scientific and engineering articles: Counts of citable documents recorded in SCImago } \\
\text { Journal \& Country Rank (based on information contained in the Scopus database). }\end{array}$ & $\begin{array}{c}\text { Per mil. } \\
\text { people }\end{array}$ & SCImago (2016) & 0 \\
\hline $\begin{array}{l}\text { USPTO patent applications: Counts of applications for utility patens filed in the United } \\
\text { States Patent and Trademark Office (USPTO) classified by country of residence of the first } \\
\text { named inventor. }\end{array}$ & $\begin{array}{l}\text { Per mil. } \\
\text { people }\end{array}$ & USPTO (2014) & 0 \\
\hline $\begin{array}{l}\text { R\&D expenditures: Intramural expenditure on research and experimental development } \\
\text { (R\&D) performed on the national territory. }\end{array}$ & $\%$ of GDP & $\begin{array}{l}\text { UNESCO (2015), OECD (2015), Castellacci } \\
\text { and Natera, (2011) and national sources }\end{array}$ & 34 \\
\hline $\begin{array}{l}\text { Internet users: Internet users are individuals who have access to the Internet (from any } \\
\text { location or device). }\end{array}$ & $\begin{array}{l}\text { Per } 100 \\
\text { people }\end{array}$ & World Bank (2014) & 0 \\
\hline $\begin{array}{l}\text { Tertiary attainment: People aged } 25 \text { and over whose highest schooling level attained is } \\
\text { tertiary. }\end{array}$ & $\%$ & Barro and Lee (2010) & 24 \\
\hline $\begin{array}{l}\text { Secondary attainment: People aged } 25 \text { and over whose highest schooling level attained } \\
\text { is secondary. }\end{array}$ & $\%$ & Barro and Lee (2010) & 24 \\
\hline $\begin{array}{l}\text { Primary attainment: People aged } 25 \text { and over whose highest schooling level attained is } \\
\text { primary. }\end{array}$ & $\%$ & Barro and Lee (2010) & 24 \\
\hline $\begin{array}{l}\text { Literacy rate: People aged } 15 \text { and over who can read, understand a write a short, simple } \\
\text { statement on their everyday life. }\end{array}$ & $\%$ & World Bank (2015) & 1 \\
\hline $\begin{array}{l}\text { Bureaucracy quality: An assessment of the institutional strength and quality of the } \\
\text { bureaucracy, which represents a shock absorber that tends to limit revisions of policy when } \\
\text { governments change. }\end{array}$ & Index & PRS Group (2014) & 14 \\
\hline $\begin{array}{l}\text { Corruption: An assessment of corruption within the political system not only in the form } \\
\text { of financial corruption but also excessive patronage, nepotism, job reservations and 'favor- } \\
\text { for-favors', secret party funding, and suspiciously close ties between politics and business. }\end{array}$ & Index & PRS Group (2014) & 14 \\
\hline $\begin{array}{l}\text { Law and order: An assessment of the "Law" element, in which the strength and } \\
\text { impartiality of the legal system are considered, and the "Order" element, which is an } \\
\text { assessment of popular observance of the law. }\end{array}$ & Index & PRS Group (2014) & 14 \\
\hline Bureaucracy and policy consistency: An assessment of the quality of the country's & Index & Global Insight Business Risk and Conditions & 1 \\
\hline
\end{tabular}


bureaucracy, how confident businesses can be of the continuity of economic policy stance and the extent to which policy-making is far-sighted, or conversely aimed at short-term economic advantage.

Corruption: An assessment of the intrusiveness of the country's bureaucracy. The amount of red tape likely to be countered is assessed, as is the likelihood of encountering corrupt officials and other groups.

Judicial independence and crime: An assessment of how far the state and other outside actors can influence and distort the legal system and how much of a threat businesses face from crime.

Quality and excessiveness of bureaucracy: An assessment of institutional effectiveness and the extent of red tape.

Corruption: An assessment of corruption among public officials.

Rule of law: An assessment of the legal system in terms of fairness of judicial process, enforceability of contracts, speediness of judicial process, the risk of confiscation and expropriation, intellectual property rights protection, private property protection and the extent of violent and organized crime.

Export demand by product: Growth in world demand weighted by the initial commodity composition of each country's exports.

Export demand by market: Growth in world demand weighted by the initial market composition of each country's exports.

Export openness: Exports of goods and services.

Population: All residents regardless of legal status or citizenship; except for refugees not permanently settled in the country of asylum, who are generally considered part of the population of their country of origin.

Natural resource rents: The sum of oil rents, natural gas rents, coal rents (hard and soft)

mineral rents, and forest rents.
(WMO) - data retrieved from Kaufmann, et al. (2014)

Global Insight Business Risk and Conditions

(WMO) - data retrieved from Kaufmann, et

al. (2014)

Global Insight Business Risk and Conditions

Index

(WMO) - data retrieved from Kaufmann, et

al. (2014)

Economic Intelligence Unit (EIU) - data retrieved from Kaufmann, et al. (2014)

Economic Intelligence Unit (EIU) - data

retrieved from Kaufmann, et al. (2014)

Economic Intelligence Unit (EIU) - data retrieved from Kaufmann, et al. (2014)

Index

Index

UNCTAD (2014)

Index

$\%$ of GDP

UNCTAD (2014)

World Bank (2015)

People

World Bank (2015)

$\%$ of GDP

World Bank (2015) 
Table A1. Government effectiveness: Results of the factor analysis

Bureaucracy quality (PRS)

Factor loadings

Bureaucracy and policy consistency (WMO)

Quality and excessiveness of bureaucracy (EIU)

0.90

0.91

Note: $78.1 \%$ of total variance explained, the extraction method is principal factors, oblique oblimin rotation, based on pooled data in 114 countries in 1995 and 2013, hence 228 observations in total.

Table A2. (Lack of) corruption: Results of the factor analysis

\begin{tabular}{l|c} 
& Factor loadings \\
\hline Corruption (PRS) & 0.79 \\
Corruption (WMO) & 0.89 \\
Corruption (EIU) & 0.93
\end{tabular}

Note: $76.2 \%$ of total variance explained, the extraction method is principal factors, oblique oblimin rotation, based on pooled data in 114 countries in 1995 and 2013, hence 228 observations in total.

Table A3. Law and order: Results of the factor analysis

\begin{tabular}{l|c} 
& Factor loadings \\
\hline Law and order (PRS) & 0.79 \\
Judicial independence and crime (WMO) & 0.95 \\
Rule of law (EIU) & 0.94
\end{tabular}

Note: $79.8 \%$ of total variance explained, the extraction method is principal factors, oblique oblimin rotation, based on pooled data in 114 countries in 1995 and 2013, hence 228 observations in total. 
Table A4. Groups of countries by capabilities

\begin{tabular}{|c|c|c|c|}
\hline Laggards & Catch-up & Transition & Developed \\
\hline Algeria & Argentina* & Albania* & Australia \\
\hline Angola & Bahrain* & Armenia & Austria \\
\hline Bangladesh & Bolivia & Azerbaijan & Belgium \\
\hline Burkina Faso & Brazil & Belarus & Canada \\
\hline Cambodia & Chile & Bulgaria & Cyprus \\
\hline Cameroon & China & Croatia & Czech Rep. \\
\hline Dem. Rep. of Congo & Colombia & Ecuador & Denmark \\
\hline Cote d'Ivoire* & Costa Rica & Georgia* & Estonia \\
\hline Egypt & Dominican Rep. & Kazakhstan & Finland \\
\hline Ethiopia* & Indonesia & Kyrgyzstan* & France \\
\hline Ghana* & Jamaica* $^{*}$ & Latvia & Germany \\
\hline Guatemala & Jordan & Macedonia & Greece \\
\hline India & Kenya & Moldova & Hong Kong* \\
\hline Iran & Kuwait* & Russia & Hungary \\
\hline Madagascar & Lithuania & Tajikistan & Iceland* \\
\hline Malawi & Malaysia & Turkmenistan* & Ireland \\
\hline Mali & Malta* & Ukraine & Israel \\
\hline Morocco & Mexico & Uzbekistan* & Italy \\
\hline Mozambique & Oman & & Japan \\
\hline Niger* & Peru & & Korea \\
\hline Nigeria & Philippines & & Luxembourg \\
\hline Pakistan & Qatar* & & Netherlands \\
\hline Senegal & Romania & & New Zealand \\
\hline Tanzania & Saudi Arabia* & & Norway \\
\hline Tunisia & Slovakia & & Poland \\
\hline Uganda & South Africa & & Portugal \\
\hline Yemen* & Sri Lanka & & Singapore* \\
\hline \multirow[t]{7}{*}{ Zambia } & Thailand & & Slovenia \\
\hline & Trinidad and Tobago & & Spain \\
\hline & Turkey & & Sweden \\
\hline & United Arab Emirates & & Switzerland \\
\hline & Uruguay & & United Kingdom \\
\hline & Venezuela & & United States \\
\hline & Vietnam & & Taiwan* \\
\hline
\end{tabular}

*) Data for adjusted net national income per capita are not available.

${ }^{1}$ Cited after Soete et al (2010), p. 1161.

${ }^{2}$ The issues covered in this section are surveyed in greater depth in Fagerberg and Srholec (2009) and Fagerberg, Srholec and Verspagen (2010) on which the discussion here draws.

${ }^{3}$ To the extent that differences in income and productivity across countries remained, these would, according to the theory, largely be due to differences in saving behavior and/or demographic trends. 


\footnotetext{
${ }^{4}$ To the best of our knowledge the first to use this concept in print was by Kim (1980). It quickly became widely used, see for example Fransman and King (1984) and Lall (1987). For a survey and an application to the national level see Lall (1992).

${ }^{5}$ It may be noted that Kim's definition of technological capability is quite similar to the notion of "absorptive capacity" (Cohen and Levinthal 1990), and Kim used the two terms interchangeably.

${ }^{6}$ Cimoli et al. (2009, p. 536) also use the term technological capability but in a slightly narrower sense, excluding Kim's production capability (which they call "production capacity").

${ }^{7}$ See Adelman and Morris (1965), Temple (1998), Temple and Johnson (1998) and Fagerberg and Srholec (2008) for earlier applications of factor analysis to cross-sections of countries.

${ }^{8}$ Note that when it comes to measuring the quality of a country's governance, we have several sources of relevant information for each of the "sub-dimensions" taken into account here. Following Srholec and Verspagen (2012), therefore, a two-stage hierarchical approach to factor analysis was used. In the first stage information for each sub-dimension was synthesized into a common factor, which was then used in the second stage. See the Appendix for results of the first-stage factor analysis.

${ }^{9}$ See Fagerberg and Srholec (2009) for a discussion of how such factors may be explored (for a more limited set of countries).

${ }^{10}$ The growth of a country arguably depends not only supply factors but also on (external) demand, which, following Fagerberg (1987), is included here as a possible additional exogenous variable The impact on a country's economy also depends on the size of the export sector (which hence is included here as an additional control variable), the effect of which needs to be adjusted by size of the economy (which is why population is included).

${ }^{11} \log$ of the initial level of the respective dependent variable is used to account for the initial development level, i.e. the scope for imitation, except only of the first estimate, in which log of the initial GDP per capita is used for that purpose.
} 